\title{
SYNTHESIS OF COPPER OXIDE NANOPARTICLES BY CHEMICAL PRECIPITATION METHOD FOR THE DETERMINATION OF ANTIBACTERIAL EFFICACY AGAINST STREPTOCOCCUS SP. AND STAPHYLOCOCCUS SP.
}

\author{
SHRADDHA SHIRSAT ${ }^{1}$, DHANASHRI PAWAR ${ }^{1}$, NISHITA JAIN ${ }^{1}$, JAYANT PAWAR ${ }^{2}$, VIDYA S TALE ${ }^{1 *}$, RABINDER HENRY \\ ${ }^{1}$ Department of Microbiology, Bharati Vidyapeeth Deemed University, Rajiv Gandhi Institute of IT and Biotechnology, Pune, \\ Maharashtra, India. ${ }^{2}$ Pralhad P. Chhabria Research Center, Pune, Maharashtra, India. Email: vstale@gmail.com
}

Received: 29 January 2019, Revised and Accepted: 27 March 2019

\section{ABSTRACT}

Objective: To determine antimicrobial efficacy of copper oxide nanoparticles (CuO NPs) against Streptococcus sp. and Staphylococcus sp.

Methods: $\mathrm{CuO}$ NPs were synthesized using chemical precipitation method. The reducing agent, $0.1 \mathrm{M} \mathrm{NaOH,} \mathrm{was} \mathrm{used} \mathrm{along} \mathrm{with} 100 \mathrm{mM}$ CuSO 4 precursor for the synthesis of CuO NPs. The characterization of CuO NPs was done by ultraviolet-visible spectroscopy and scanning electron microscopy (SEM) to study optical and morphological characteristics, correspondingly. The identification of bacterial cultures was done through microscopic and biochemical studies. Antibacterial efficacy of CuO NPs was determined against Streptococcus sp. and Staphylococcus sp. by qualitative and quantitative methods through anti-well diffusion assay and broth dilution method, respectively.

Results: The absorption spectrum and band gap were found to be at $260 \mathrm{~nm}$ and $4.77 \mathrm{eV}$, respectively. The SEM image of CuO NPs shows cluster of nanostructures having width of individual clusters in the range of $100 \mathrm{~nm}-500 \mathrm{~nm}$. CuO NPs showed inhibition at a concentration ranging from $60 \mu \mathrm{g} / \mathrm{mL}$ to $1000 \mu \mathrm{g} / \mathrm{mL}$.

Conclusion: Finally, CuO NPs can be used as effective antibacterial agent against Streptococcus sp. and Staphylococcus sp. and may have applications in medical microbiology.

Keywords: Chemical precipitation, Copper oxide nanoparticles, Antibacterial activity, Streptococcus sp., Staphylococcus sp.

(C) 2019 The Authors. Published by Innovare Academic Sciences Pvt Ltd. This is an open access article under the CC BY license (http://creativecommons. org/licenses/by/4. 0/) DOI: http://dx.doi.org/10.22159/ajpcr.2019.v12i5.32270

\section{INTRODUCTION}

The compounds that locally kill bacteria or slow down their growth exhibit antibacterial activity. These compounds are generally not toxic to the surrounding tissue. Most current antibacterial agents are chemically modified natural compounds [1] such as $\beta$-lactams (like penicillins), cephalosporins, or carbapenems. In general, the agents can be classified as either bactericidal, which kill bacteria, or bacteriostatic, slowing down bacterial growth.

These antibacterial agents are vital to fight against infectious diseases. However, overuse of such agents has found ineffective and developed resistance in bacteria. Such resistance is most often based on evolutionary processes taking place during antibiotic therapy and leads to inheritable resistance [2]. Such kind of antibacterial-resistant strains and species are unofficially referred to as superbugs and contribute to the appearance of diseases that were under good control for many years. Thus, due to the fact that bacteria developed resistance against many common antibacterial agents, infectious diseases continue to be one of the greatest health challenges worldwide. For conventional antimicrobial agents, the development of multiple drug resistance is not the only downside but also undesirable side effects. Drug resistance enforces high-dose administration of antibiotics and generates unendurable toxicity.

This has driven the development of alternative strategies to treat bacterial diseases [3]. The development of nanoscale materials has emerged as novel antimicrobial agents. Several classes of antimicrobial nanoparticles (NPs) and nanocarriers for antibiotics delivery have proven their efficiency for treating infectious diseases including antibiotic-resistant ones, in vitro, as well as in animal models [4]. NPs offer improved properties to classical organic antibacterial agents for various reasons; one reason lies in their high surface area to volume ratio, resulting in appearance of new mechanical, chemical, electrical, optical, magnetic, electro-optical, and magneto-optical properties of the NPs that are different from their bulk properties [5].

When particles are reduced from a micrometer to a nanometer size, their resultant properties can change considerably. Such characteristics allow them to interact closely with bacterial membranes, rather than the effect being only due to the release of metal ions [6]. In theory, metal NPs could be combined with polymers or coated onto surfaces, which may then have a variety of potential antimicrobial applications. The antimicrobial properties of both silver [7] and copper NPs [8] have been reported in the past and both of these have been coated onto or incorporated into various materials [9]. Copper oxide (CuO)/copper (II) oxide/cupric oxide is a semiconducting compound with a monoclinic structure. $\mathrm{CuO}$ is the simplest member of the family of copper compounds and it exhibits a range of potentially useful physical properties such as high-temperature superconductivity, electron correlation effects, and spin dynamics $[10,11]$. However, the information on the possible antimicrobial activity of nano-CuO is limited. $\mathrm{CuO}$ is cheaper than silver and can be easily mixed with polymers. They are relatively stable in terms of both chemical and physical properties. The ionic nanoparticulate metal oxides, such as $\mathrm{CuO}$, can be particularly important antimicrobial agents as they have exceptionally high surface areas and unusual crystal morphologies [12]. The aim of this study is to synthesize and characterize CuO NPs and to further examine its possible antimicrobial properties. 


\section{METHODS}

Sample collection, isolation, and biochemical characterization The bacterial isolates were collected from the Department of Microbiology, RGITBT and were further characterized for their physiological and biochemical characteristics. Gram staining, capsule staining, sugar fermentation test, citrate utilization test, catalase test, methyl red test, and blood agar test were performed to characterize bacterial isolates.

\section{Synthesis and characterization of CuO NPs}

Synthesis of CuO NPs by chemical precipitation

In typical experimental procedure, $100 \mathrm{mM}$ copper (II) sulfate pentahydrate $\left(\mathrm{CuSO}_{4} \cdot 5 \mathrm{H}_{2} \mathrm{O}\right)$ was dissolved in $50 \mathrm{~mL}$ of distilled water by continuous stirring on magnetic stirrer at room temperature for 30 min. Simultaneously, $100 \mathrm{mM} \mathrm{NaOH}$ was prepared in distilled water and added dropwise into the $\mathrm{CuSO}_{4}$ solution with continuous stirring at room temperature. The resultant precipitate was washed by centrifugation at $6000 \mathrm{rpm}$ for $15 \mathrm{~min}$ each with deionized water and $70 \%$ ethanol. The final product was dried in hot air oven at $60^{\circ} \mathrm{C}$ for $24 \mathrm{~h}$, followed by calcination at $400^{\circ} \mathrm{C}$ for $4 \mathrm{~h}$ to obtain powder [13].

\section{Characterization of CuO NPS}

The structural and morphological features of resultant $\mathrm{CuO}$ NPs were characterized by ultraviolet (UV)-visible spectroscopy and scanning electron microscopy (SEM) for identifying their optical and morphological characteristics.

\section{Determination of antibacterial potential of CuO NPs}

Antimicrobial activity of the NPs was checked using the anti-well diffusion agar method $[14,15]$. Mueller-Hinton agar was used for this assay. Fresh inoculum $(100 \mu \mathrm{l})$ was spread onto the plates. The plates were refrigerated for $10 \mathrm{~min}$ for initial attachment of the microbes. CuO NPs of various dilutions $(20,40,60,120,250,500$, and $1000 \mu \mathrm{g} / \mathrm{ml})$ were prepared and $20 \mu \mathrm{l}$ of $\mathrm{CuO}$ NPs were added in each well, respectively. The plates were incubated at $37^{\circ} \mathrm{C}$ for $24 \mathrm{~h}$. The zone of inhibition was measured and susceptibility of the $\mathrm{CuO}$ NPs was estimated at different concentrations for the determination of minimum inhibitory concentrations (MICs).

\section{RESULTS}

\section{Characterization of isolated bacteria}

Six bacterial isolates were maintained on MSA medium and studied for their colony characteristics (Table 1). Gram staining was performed. Two isolates were further studied for the identification on the basis of biochemical characterization (Table 2).

\section{Characterization of CuO NPs}

UV-visible spectroscopy (Thermo Scientific UV-10) was used to study an optical property of CuO NPs. Spectroscopic results clearly indicated the production of $\mathrm{CuO}$ NPs. Absorption spectrums of $\mathrm{CuO} \mathrm{NPs} \mathrm{are} \mathrm{shown} \mathrm{in}$
Fig. 1. The maximum absorption of synthesized CuO NPs synthesized by chemical precipitation was found to be at $260 \mathrm{~nm}$ and the band gap was calculated to be $4.77 \mathrm{eV}$. The SEM image of CuO NPs shows a cluster of nanostructures having length and width of few microns. However, the width of individual clusters has found to be in the range of 100 nm-500 nm (Fig. 2).

\section{Antibacterial efficacy of CuO NPs by anti-well diffusion assay}

Antibacterial activity of $\mathrm{CuO}$ NP performed by anti-well diffusion assay indicated inhibition of both Streptococcus sp. and Staphylococcus sp. Zone of inhibition was observed at concentrations ranging from $60 \mu \mathrm{g} / \mathrm{mL}$ to $1000 \mu \mathrm{g} / \mathrm{mL}$ (Figure 3). No inhibition was observed at concentrations ranging from $10 \mu \mathrm{g} / \mathrm{mL}$ to $50 \mu \mathrm{g} / \mathrm{mL}$. MIC was observed at $60 \mu \mathrm{g} / \mathrm{mL}$.

\section{DISCUSSION}

Synthesis of CuO NPs was performed successfully using chemical reduction method. The CuO NPs showed remarkable antibacterial activity against Streptococcus sp. and Staphylococcus sp. A few studies have been performed to reveal the mechanism of bactericidal action of NPs. It is difficult to distinguish between the bactericidal activities of NPs from the ions released by the NPs themselves [16]. Ruparelia et al. estimated the concentration of released ions for $10 \mathrm{mg}$ of copper NPs suspended in $100 \mathrm{~mL}$ nutrient media and distilled water [17]. They found that the concentration of $\mathrm{Cu} 2+$ ions released in nutrient media was $17 \mathrm{mg} / \mathrm{L}$ after $24 \mathrm{~h}$ of incubation in a rotary shaker, while in distilled water under the same conditions over a period of $24 \mathrm{~h}$, the concentration of ions released was $0.5 \mathrm{mg} / \mathrm{L}-1 \mathrm{mg} / \mathrm{L}$. These results indicate that the nutrient media can facilitate the release of $\mathrm{Cu} 2+$ ions. The considerably greater release of $\mathrm{Cu} 2+$ ions in the nutrient media is possibly due to the interaction of the media chloride ions with the oxide layer of the NPs [17]. Consequently, the bactericidal effects observed in this study might have been influenced by the release of $\mathrm{Cu} 2+$ ions in solution. The presence of NPs in suspension would ensure continuous release of ions into the nutrient media [18]. There are a few mechanisms of NPs toxicity suggested by other works. For example, copper ions released by the NPs may attach to the negatively charged bacterial cell wall and rupture it, thereby leading to protein denaturation and cell death [19]. Copper ions inside the bacterial cells may bind to deoxyribonucleic acid molecules and form cross-linking within and between the nucleic acid strands, resulting in the disorganized helical structure. In addition, copper ion uptake by the bacterial cells has also been found to damage important biochemical processes [20,21].

In the study conducted by Jeyaraman et al., copper NPs displayed antibacterial activity toward the tested pathogenic strains of Micrococcus luteus, Staphylococcus aureus, Escherichia coli, Klebsiella pneumonia, and Pseudomonas aeruginosa; in a similar manner, antifungal activity was observed toward Aspergillus flavus, Aspergillus niger, Candida albicans, and respectively. Bacillus subtilis

Table 1: Gram staining and colony characteristics of bacterial isolates

\begin{tabular}{llllll}
\hline Color & Opacity & Consistency & Elevation & Gram nature & Capsule staining \\
\hline Off white & Opaque & Sticky & Flat & Gram +ve & $+v e$ \\
\hline
\end{tabular}

Table 2: Biochemical test for the identification of isolates

\begin{tabular}{lllllll}
\hline Isolate & Sugar fermentation & Citrate utilization test & Catalase test & Methyl red test & Blood agar test & $\begin{array}{l}\text { Tentative } \\
\text { identification }\end{array}$ \\
\hline 1 & $\begin{array}{l}\text { Lactose+ve } \\
\text { Mannitol+ve }\end{array}$ & $+\mathrm{ve}$ & $-\mathrm{ve}$ & $+\mathrm{ve}$ & Gamma-hemolysis & Streptococcus species \\
& $\begin{array}{l}\text { Lactose+ve } \\
\text { Mannitol-ve }\end{array}$ & -ve & +ve & $+\mathrm{ve}$ & B-hemolysis & Staphylococcus species \\
\hline
\end{tabular}


depicted the highest sensitivity to NPs compared to the other strains and was more adversely affected by the copper NPs that were observed between the inhibition zone observed in disk diffusion test and MIC/ minimum bactericidal concentration determined based on liquid cultures with the various strains [22]. Pawar et al. reported the antibacterial activity of CuO NPs against food pathogen B. cereus [23]. In another study conducted by Azam et al., it was found that CuO NPs

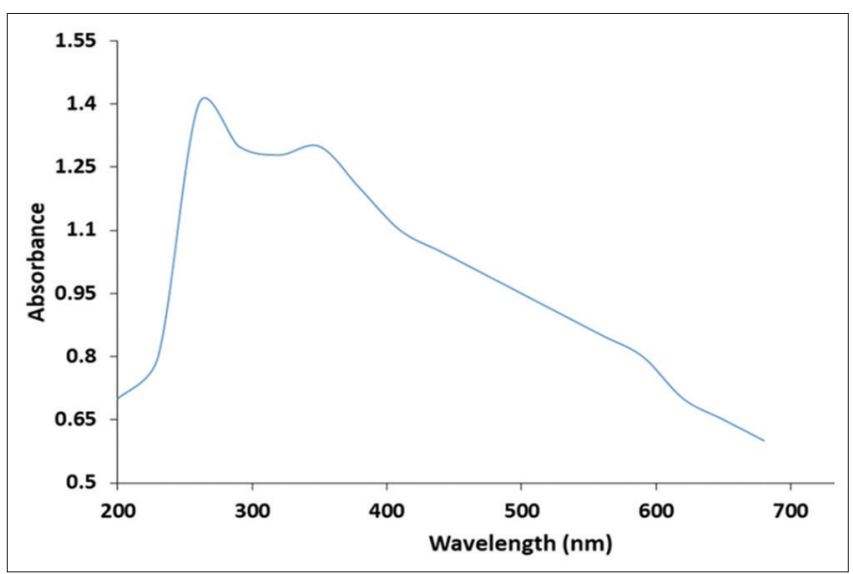

Fig. 1: Ultraviolet-visible spectroscopy of copper oxide nanoparticles

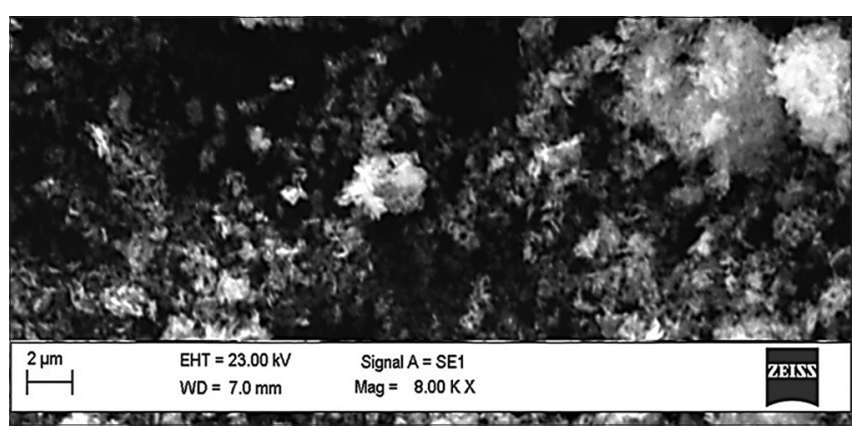

Fig. 2: Scanning electron microscopy images of copper oxide nanoparticles have shown greater antimicrobial activity against $B$. subtilis and $S$. aureus. The variation in the sensitivity or resistance to both Grampositive and Gram-negative bacteria populations could be due to the differences in the cell structure, physiology, metabolism, or degree of contact of organisms with NPs. For example, greater sensitivity among Gram-positive bacteria such as $B$. subtilis and $S$. aureus to the $\mathrm{CuO}$ NPs has been attributed to the greater abundance of amines and carboxyl groups on their cell surface and greater affinity of copper toward these groups [24]. Alternatively, Gram-negative bacteria like E. coli have a special cell membrane structure which possesses an important ability to resist antimicrobial agents. Furthermore, other factors such as NP diffusion rates may also affect bacterial strain differently. The study indicates that the CuO NPs inhibit the growth of both Gram-negative and Gram-positive bacteria and the zone of inhibition decreases with the increase in annealing temperature from $400^{\circ} \mathrm{C}$ to $700^{\circ} \mathrm{C}$, the zone of inhibition is maximum when the particle size is minimum $(20 \pm 1.24 \mathrm{~nm})$. These results demonstrate the excellent antimicrobial behavior of $\mathrm{CuO}$ NPs synthesized at low temperature. The interactions between the negative charges of microorganisms and the positive charge of NPs produce an electromagnetic attraction between the microbe and effective levels of active NPs. Such interactions lead to oxidation of surface molecules of microbes resulting in their death.

\section{CONCLUSION}

$\mathrm{CuO}$ NPs were synthesized by chemical precipitation method. $\mathrm{CuO}$ NP is characterized by UV-visible spectroscopy and SEM. Synthesized $\mathrm{CuO} \mathrm{NP}$ has shown antimicrobial activity against Staphylococcus and Streptococcus sp. Considering increased antibiotic resistance in pathogenic microorganisms, CuO NP should become cost-effective alternative for the development of antimicrobial agent against pathogenic microorganisms.

\section{AUTHORS' CONTRIBUTIONS}

SS, DP, and NJ contributed in experimental data generation, data analysis, and collated the published literature in similar domain. VT, JP, and RH guided the work, drafted the manuscript, and critical revision. All authors read and approved the final manuscript.

\section{CONFLICTS OF INTEREST}

The authors declare that they have no conflicts of interest.

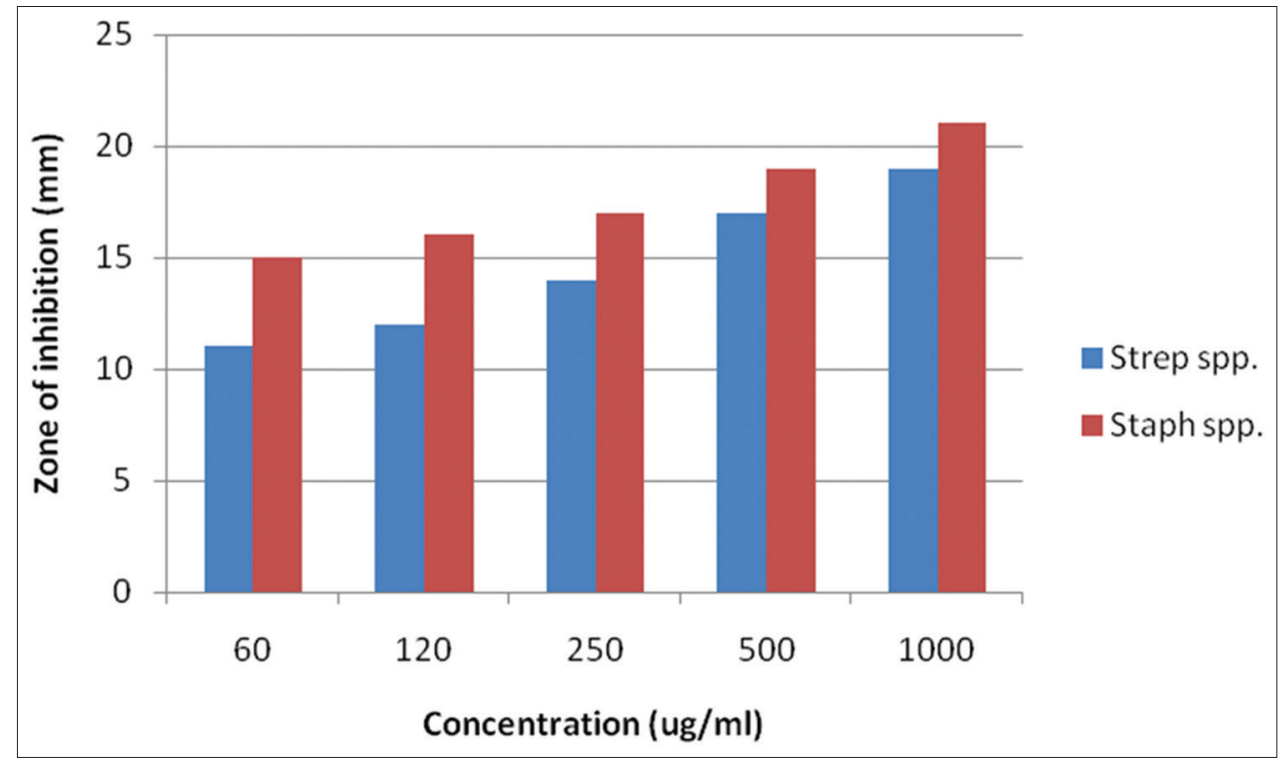

Fig. 3: Comparison of antimicrobial activity of isolates using various copper oxide nanoparticle concentrations 


\section{REFERENCES}

1. von Nussbaum F, Brands M, Hinzen B, Weigand S, Häbich D. Antibacterial natural products in medicinal chemistry exodus or revival? Angew Chem Int Ed Engl 2006;45:5072-129.

2. Witte W. International dissemination of antibiotic resistant strains of bacterial pathogens. Infect Genet Evol 2004;4:187-91.

3. Baker-Austin C, Wright MS, Stepanauskas R, McArthur JV. Coselection of antibiotic and metal resistance. Trends Microbiol 2006; $14: 176-82$

4. Huh AJ, Kwon YJ. "Nanoantibiotics": A new paradigm for treating infectious diseases using nanomaterials in the antibiotics resistant era. J Control Release 2011;156:128-45.

5. Whitesides GM. Nanoscience, nanotechnology, and chemistry. Small 2005; $1: 172-9$

6. Morones JR, Elechiguerra JL, Camacho A, Holt K, Kouri JB, Ramírez JT, et al. The bactericidal effect of silver nanoparticles. Nanotechnology 2005;16:2346-53.

7. Sondi I, Salopek-Sondi B. Silver nanoparticles as antimicrobial agent: A case study on E. Coli as a model for gram-negative bacteria. J Colloid Interface Sci 2004;275:177-82.

8. Cioffi N, Torsi L, Ditaranto N, Tantillo G, Ghibelli L, Sabbatini L, et al. Copper nanoparticle/polymer composites with antifungal and bacteriostatic properties. Chem Mater 2005;17:5255-62.

9. Li Z, Lee D, Sheng X, Cohen RE, Rubner MF. Two-level antibacterial coating with both release-killing and contact-killing capabilities. Langmuir 2006;22:9820-3.

10. Cava RJ. Structural chemistry and the local charge picture of copper oxide superconductors. Science 1990;247:656-62.

11. Tranquada JM, Sternlieb BJ, Axe JD, Nakamura Y, Uchida S. Evidence for stripe correlations of spins and holes in copper oxide superconductors. Nature 1995;375:561

12. Stoimenov PK, Klinger RL, Marchin GL, Klabunde KJ. Metal oxide nanoparticles as bactericidal agents. Langmuir 2002;18:6679-86.

13. Phiwdanga K, Suphankija S, Mekprasarta W, Wisanu P. Synthesis of $\mathrm{CuO}$ nanoparticles by precipitation method using different precursors.
Energy Proc 2013;34:740-5

14. Singh K, Tafida GM. Antibacterial activity of Moringa oleifera (Lam) leaves extracts against some selected bacteria. Int J Pharm Pharm Sci 2014;6:52-4.

15. Tyor A, Kumari S. Biochemical characterization and antibacterial properties of fish skin mucus of fresh water fish, hypophthalmichthys nobilis. Int J Pharm Pharm Sci 2016;8:132-6.

16. Yoon KY, Hoon Byeon J, Park JH, Hwang J. Susceptibility constants of Escherichia coli and Bacillus subtilis to silver and copper nanoparticles. Sci Total Environ 2007;373:572-5

17. Ruparelia JP, Chatterjee AK, Duttagupta SP, Mukherji S. Strain specificity in antimicrobial activity of silver and copper nanoparticles. Acta Biomater 2008;4:707-16.

18. Cioffi N, Ditaranto N, Torsi L, Picca RA, Sabbatini L, Valentini A, et al. Analytical characterization of bioactive fluoropolymer ultrathin coatings modified by copper nanoparticles. Anal Bioanal Chem 2005;381:607-16.

19. Lin YE, Vidic RD, Stout JE, McCartney CA, Yu VL. Inactivation of Mycobacterium avium by copper and silver ions. Water Res 1998;32:1997-2000

20. Kim JH, Cho H, Ryu SE, Choi MU. Effects of metal ions on the activity of protein tyrosine phosphatase VHR: Highly potent and reversible oxidative inactivation by $\mathrm{cu} 2+$ ion. Arch Biochem Biophys 2000;382:72-80

21. Stohs SJ, Bagchi D. Oxidative mechanisms in the toxicity of metal ions. Free Radic Biol Med 1995;18:321-36.

22. Jeyaraman R, Subramanian J, Marikani K, Rajakumar A, Govindasamy. Synthesis and antimicrobial activity of copper nanoparticles. Mater Lett 2012;71:114-6.

23. Pawar J, Henry R, Viswanathan P, Patwardhan A, Singh EA. Testing of antibacterial efficacy of $\mathrm{CuO}$ nanoparticles by methylene blue reduction test against Bacillus cereus responsible for food spoilage and poisoning. Indian Chem Eng 2018;1:1-6.

24. Azam A, Ahmed AS, Oves M, Khan MS, Memic A. Size-dependent antimicrobial properties of $\mathrm{cuO}$ nanoparticles against gram-positive and -negative bacterial strains. Int J Nanomedicine 2012;7:3527-35. 